\title{
The German Radiological Society and the Protagonists of Radiology during the Time of National Socialism - State of Research, Explanation Attempts, Desiderata and Research Prospects
}

\section{Die Deutsche Röntgengesellschaft und die Protagonisten der Radiologie in der Zeit des Nationalsozialismus - Forschungsstand, Erklärungsansätze, Desiderate und Perspektiven}

Authors

Affiliation

\section{Schmidt, T. Winzen, D. Groß}

Institute of the History, Theory and Ethics of Medicine, RWTH Aachen University Medical School, Aachen, Germany This research project is supported by the START-Program of the Faculty of Medicine, RWTH Aachen University.

Key words

- health policy and practice

- history

- national socialism

- german radiological society

- structural developments of radiological discipline received 11.11.2014 accepted $\quad 12.12 .2014$

\section{Bibliography}

DOI http://dx.doi.org/

10.1055/s-0034-1399037

Published online: 9.4.2015

Fortschr Röntgenstr 2015; 187 :

425-429 @ Georg Thieme

Verlag KG Stuttgart · New York .

ISSN 1438-9029

\section{Correspondence}

\section{Mathias Schmidt}

Institute of the History, Theory and Ethics of Medicine, RWTH

Aachen University Medical

School, Aachen, Germany

Wendlingweg 2, MTI II

52074 Aachen

Germany

Tel.: ++49/2 41/8085102

Fax: $++49 / 241 / 8082466$

maschmidt@ukaachen.de

\section{Abstract}

$\nabla$

The intention of the authors is the recognition and critical analysis of efforts to study the history of the German Radiological Society during the time of National Socialism from 1933 to 1945 with the goal of determining existing desiderata and identifying the resulting research prospects. There is a need to study concrete individual biographies of radiologists (members of the German Radiological Society, perpetrators, and victims) and their careers before and after 1945 as well as the importance of the interdisciplinarity of the discipline and the lack of institutional involvement during the "Third Reich". Moreover, the comparatively difficult starting situation of the study of the history of the German Radiological Society is discussed.

Key Points:

- In the history of the German Radiological Society in the era of National Socialism there exist research desiderata.

- The research of the history of the society faces a number of problems that are addressed.

- The history of the German Radiological Society will provide an interesting insight into a comparatively young and interdisciplinary field.

Citation Format:

- Schmidt M, Winzen T, Groß D. The German Radiological Society and the Protagonists of Radiology during the Time of National Socialism - State of Research, Explanation Attempts, Desiderata and Research Prospects. Fortschr Röntgenstr 2015; 187: 425-429

\section{Zusammenfassung \\ $\nabla$}

Das Anliegen der Autoren ist die Würdigung und kritische Betrachtung bestehender Aufarbeitungsbestrebungen der Geschichte der Deutschen Röntgengesellschaft in der Zeit des Nationalsozialismus 1933 - 1945 mit dem Ziel, bestehende Desiderate zu ermitteln und die daraus entstehenden Forschungsperspektiven zu eröffnen. Sowohl hinsichtlich konkreter Einzelbiografien von Röntgenologen (Mitgliedern der DRG, Tätern und Opfern) und deren Karrieren vor und nach 1945 als auch hinsichtlich der Bedeutung der Interdisziplinarität des Faches und seiner zur Zeit des „Dritten Reiches“ vorherrschenden mangelnden institutionellen Verankerung gibt es Nachholbedarf. Des Weiteren wird die vergleichsweise schwierige Ausgangslage der Aufarbeitung der Geschichte der DRG näher erläutert.

State of Research, Materials and Methods $\nabla$

In recent years medical history researchers have intensively studied the role of scientists, health professionals, universities, medical schools, and medical societies during National Socialism. The theory that medicine and its protagonists were exploited by the Nazi regime, which was popular into the $1980 \mathrm{~s}$, was clearly refuted in this process. Not only the unusually high percentage of Nazi party members among contemporary physicians (approx. 50\%) but also the often voluntary Selbstgleichschaltung [self-synchronization] of medical schools and professional societies as well as the rapid expulsion of Jewish members tend to indicate a willing cooperation between medical professionals and the Nazi regime $[1-3]{ }^{1}$

\footnotetext{
${ }^{1}$ At this point we would like to thank our colleague Matthis Krischel for providing significant information and constructive criticism.
} 
A comparison of the state of research in the individual medical disciplines shows that the current initiatives of the German Radiological Society and organized radiology and its protagonists are lagging behind the efforts of many other medical societies and disciplines. Although the inclusion of Ernst Klee's article in the anniversary edition of the German Radiological Society in 2005 and Gabriele Moser's presentation at the $95^{\text {th }}$ German Radiology Congress 2014 have laid the groundwork for a critical analysis [4-8], other professional societies, e. g., the organizations of urologists, dermatologists, occupational physicians, ophthalmologists, and pediatricians, have already conducted (multiple) comprehensive and informative studies on this topic [9-18].

Ernst Klee provided a first basic look at the history of radiology in National Socialism in the indicated four-page article in the publication commemorating the $100^{\text {th }}$ anniversary of the Radiological Society from 2005 [4]. Radiation sterilizations, the expulsion of Jewish physicians, human experiments, and professional continuity after 1945 were discussed for the first time in this article in the context of the history of the German Radiological Society. However, the results were not new but rather a slightly revised version of a chapter from Klee's book "Deutsche Medizin im Dritten Reich" [German Medicine in the Third Reich] [4, 19]. Early efforts of the German Radiological Society to address the past were thus characterized by the society presenting results acquired and published in other contexts to their own scientific community; the chapter also has the ambiguous title "Röntgenverfolgung" [X-Ray Monitoring]. It focuses on radiology and several radiologists while the German Radiological Society as a professional society and its possible institutional involvements are not addressed. In 2010 the German Radiological Society commissioned historian Gabriele Moser to study the history of the professional societies in the Third Reich, which was followed by a similar project by the German Society for Radiooncology (DEGRO) in 2012 [5, 20]. Moser compiled a list of 165 radiologists who were classified as Jewish according to Nazi laws and lost their license to practice medicine in 1938 [20]. Moreover, she was able to present the current research results in the form of a presentation at the $95^{\text {th }}$ German Radiology Congress 2014 and in "Röntgenfortschritte" [Advances in Radiology]. Nevertheless, attempts made to date to address the past cannot be viewed as complete or sufficient, particularly in direct comparison with the studies of other professional societies and their results.

In addition to biographies, the role of leading experts, and professional continuity after 1933 and 1945, the (self-) synchronization of a professional society, the development of the discipline, the relationship to race ideology and national health, the expulsion and emigration of Jewish members, the process of coming to terms with the past and dealing with its own history after 1945 are typically at the center of research regarding medical professional societies in the "Third Reich" and in the post-war period [21, 22].

Against this backdrop, the goal of the present article is to classify the current state of research, to identify research goals, to provide possible explanations for current gaps in research, and to determine concrete research prospects.

The article is based on a systematic analysis and review of the relevant secondary literature, analysis of the degree of specialization of radiology during the "Third Reich" and on a partial review of archives. These include the Federal Archive Berlin, the Federal Archive-Military Archive Freiburg, the Archive of the German Röntgen Museum, and various university and municipal archives.

\section{Radiology and National Socialism - attempts to explain an unresolved relationship $\nabla$}

As already indicated, the German Radiological Society is comparatively late to address its role in the "Third Reich". However, this circumstance alone cannot explain the still insufficient state of research and the still underestimated need for research.

In fact, the situation of the German Radiological Society and its representatives in the years between 1933 and 1945 differed in our opinion in multiple regards from that of many other medical societies - a fact that has complicated and continues to complicate the necessary reappraisal of the past. The major reasons for this are (1) biographical anomalies and difficulties that affect the state of research, (2) the comparatively minimal level of institutionalization - as evidenced by the low number of professorships and chairs by 1945 - and a still comparatively heterogeneous professional qualification, (3) source-related obstacles and (4) the special role of the discipline and its specific functions in the framework of Nazi medicine, namely in the areas of radiation sterilization and human experiments. All aspects will be discussed more closely in the following.

\section{Biographical anomalies and difficulties}

Review of the people in question for orientation purposes shows that many relevant radiologists and members of the German Radiological Society died before 1945 or at the end of the 1940 s/start of the 1950 s so that they didn't have to answer for their actions after the war or start a post-war career that may have attracted the attention of the public and relevant research:

For example, Karl Frik, head of the German Radiological Society from 1934 to 1938, died in 1944 [4]. Hans Holfelder, who was the head of the SS-Röntgensturmbann [X-Ray Battalion] and a professor in Frankfurt, died at the end of 1944 $[23,24]$. Friedrich Berner, who was an SS-Hauptsturmführer [SS captain], head of the Hadamar euthanasia center, and another member of the Röntgensturmbann, died in 1945 [25]. Carl Hermann Lasch, who was the deputy chairperson of the German Radiological Society starting in 1938 and was later employed at the University of Poznan, has been missing since 1945 [26]. Rudolf Grashey (1876 - 1950) was a cofounder of the German Radiological Society in 1905 and a longtime editor of "Fortschritte auf dem Gebiet der Röntgenstrahlen" and starting in 1928/29 became the first person to hold the position of a permanent chair of radiology in Germany [27]. Fedor Haenisch (1874-1952) served from 1913 to 1945 as the head physician of the radiology department of the General Hospital Hamburg-Barmbek. For the years 1933 to August 1943, he is listed as a member of the Nazi party and various other party organizations such as the German Labor Front and the National Socialist People's Welfare. The reasons for the termination of his party membership in 1943 must still be clarified [28]. Carl Alexander Lorey $(1880-1949)$ helped to establish the radiology de- 
partment at the University Medical Center Hamburg-Eppendorf before becoming the head physician at the Bethanien Hospital in Hamburg in 1934. Any involvement in National Socialism is not known, but comprehensive biographical research has not yet been performed [29]. A study of the biographies of leading members of the German Radiological Society and relevant radiologists in the years from 1930 to 1955 is currently being performed by the authors.

\section{Low level of institutionalization and heterogeneous qualification}

In addition, radiology was a relatively new and not yet fully developed discipline that had not yet become fully established at universities when the National Socialists seized power. Therefore, chairs had only been established in Cologne, Frankfurt, Hamburg, Berlin, and Leipzig by 1945. Many radiology departments were run by dependent institute or department heads, who in most cases were "only" so-called "also radiologists", i.e., physicians with a double qualification or specialists in other disciplines who also worked with radiation $[27,30]$. In light of this, it is not surprising that the comprehensive study of the history of the medical schools in the past two decades has provided little indication of the involvement of physicians working in radiology. For these reasons, conclusive information also cannot be expected in the future. In addition, with respect to the professional society, the extent to which the mentioned "also-radiologists" wanted membership in the German Radiological Society, felt connected to the society, and had a political interest in radiology must be determined. It can be assumed that due to the described professional profile many radiologists did not have the opportunity or possibly had little interest in reaching the highest professional and political ranks of the professional society and therefore attracted little or no attention after 1945 in medical history research.

\section{Difficult state of source materials}

Moreover, the state of source materials can be categorized as difficult: There is often a lack of comprehensive documentation for the persons in question and in many cases the extent to which person-related documents are still stored at hospitals and individual departments and are accessible for research must be clarified. This is further complicated by the above-mentioned early death of all protagonists of this discipline. Incomplete records regarding the history of the German Radiological Society also complicate the situation. The incomplete nature of the records of the history of the german radiological society obsure the situtation. Additionally, the archival records of the Society in the German Röntgen Museum are from the post-war period [20].

Special role of the discipline and its specific functions in Nazi medicine

A look at possible discipline-specific involvement of contemporary radiologists in Nazi health policy highlights two fields of action: The radiation sterilizations performed during the "Third Reich" and the human experiments involving $\mathrm{X}$-rays performed in the concentration camps.
In contrast to the euthanasia crimes, radiation sterilization was legally authorized. Even after 1945 under the occupying forces and in the early federal republic, such procedures were not fundamentally viewed as a crime from a legal standpoint and were thus given comparatively little attention even in post-war Germany. The need to address this topic has been largely "overlooked" for a long time [31, 32]. Quantitative aspects presumably contributed to this: In total, the number of radiation sterilizations compared to surgical procedures is estimated to be low. However, Behrendt and Schäfer stated that these numbers can deceive since the Reichsärztekammer [Reich Physicians' Chamber] criticized the high number of radiation sterilizations performed for the purpose of making the subject infertile without indication in $1941[27,33]$. Consequently, procedures were presumably not or not fully registered.

The (currently known) human experiments involving $\mathrm{X}$ rays in the concentration camps are complex and difficult to categorize. They were not performed by radiology specialists (so-called "only radiologists") but by "also radiologists". When radiology specialists were involved, the experiments were not X-ray or radiation experiments. For example, starting in 1937 the radiologist Georg August Weltz was a member of the advisory board of the German Radiological Society and Sigmund Rascher's supervisor for the infamous high-altitude experiments at the Dachau concentration camp. He was acquitted at the Nuremberg Doctors' Trial [34, 35]. However, the gynecologist Karl Ehrhardt experimented with X-ray contrast agents in fetuses to study intrauterine life processes. Carl Clauberg (also a gynecologist) sought an alternative X-ray contrast agent, and the surgeon Horst Schumann tested methods for mass sterilization, including exposure to radiation [36].

\section{Research goals and perspectives}

The apparent lack of or relatively low participation of the members of the German Radiological Society in the NS regime is most likely due to scarce archival resources and the lateness at which the society began to study its past. It is also caused by the other special circumstances mentioned in previous paragraphs.

Despite, or rather because of, the difficult state of source materials and the other difficulties, additional research regarding the biographies of leading radiologists and members of the German Radiological Society and their political commitment, e.g. in the form of party and organization memberships or important offices, is essential. Specific research questions are particularly important in this regard. The attitude of the physicians working in radiology and their participation in the race-related goals and activities of the regime must be determined in order to be able to reliably assess the extent of their personal involvement. Questions regarding professional continuity in the careers of the representatives of the discipline after 1945, possible adaptation to the new political systems and conditions in the early days of the federal republic and the GDR, and the degree of personal critical reflection and accountability in the post-war period must also be answered. The particular conditions, characteristics, and details of the (self-) synchronization of the professional society, its influence on 
the strengthening and consolidation of the discipline in the "Third Reich", and particularly the relationship to race ideology and national health as well as the process of coming to terms with the past and dealing with the own history after 1945 are of interest with respect to the German Radiological Society. Another insufficiently studied area is the expulsion and exclusion of colleagues and members of the German Radiological Society classified as Jewish after 1933 and their subsequent fate. Finally the acquired knowledge (a) must be analyzed and interpreted against the specific backdrop of the political development of radiology and (b) be incorporated into the context of the time of National Socialism and the post-war period in both German states after 1945.

In summary, it must be stated that the study of the history of radiology and the German Radiological Society during National Socialism is still in the early stages. In the future the identified difficulties and hurdles must be overcome and the resulting gaps in research must be filled to the greatest extent possible while taking into account the specific characteristics of radiology. These specifics make the history of the German Radiological Society - despite possible difficulties and imponderables - a fertile and promising field of research, particularly with respect to the development of the professional society of a comparatively new and interdisciplinary discipline.

\section{Acknowledgement}

This research project is supported by the START-Program of the Faculty of Medicine, RWTH Aachen University.

\section{Literatur}

1 Freimüller T. Mediziner: Operation Volkskörper. In: Frei N, Freimüller T (eds) Karrieren im Zwielicht. Hitlers Eliten nach 1945. Frankfurt am Main/New York: Campus; 2001: 13-71

2 Rüther M. Ärztliches Standeswesen im Nationalsozialismus 19331945. In: Jütte R (ed). Geschichte der deutschen Ärzteschaft. Organisierte Berufs- und Gesundheitspolitik im 19. und 20. Jahrhundert. Köln: Deutscher Ärzte Verlag; 1997: 143-193

3 Roelcke V. Psychiatrie im Nationalsozialismus. Historische Kenntnisse, Implikationen für aktuelle ethische Debatten. Der Nervenarzt 2010; 81: $1317-1325$

4 Klee E. Röntgenverfolgung - Radiologie im Dritten Reich. In: Bautz W, Busch W (eds). 100 Jahre Deutsche Röntgengesellschaft 1905-2005. Stuttgart: Thieme; 2005: 140-143

5 Moser G. Radiologie in der NS-Zeit 1: Staat, Staatsbürger, Ausgrenzung. Normalität im NS-Staat. Fortschr Röntgenstr 2014; 186: 17-21

6 Moser G. Radiologie in der NS-Zeit 2: Professionalisierung, Statuserhalt und Dienst an der „Volksgesundheit“. Fortschr Röntgenstr 2014; 186 : $116-119$

7 Moser G. Radiologie in der NS-Zeit 3: „Röntgenkunde und Volksgesundheit“: Radiologie und Röntgenologie in der NS-Erbgesundheitspolitik. Fortschr Röntgenstr 2014; 186: $212-217$

8 Moser G. Radiologie in der NS-Zeit 4: Tuberkulosebekämpfung zwischen „Volksröntgenkataster“ und SS-Röntgensturmbann. Fortschr Röntgenstr 2014; 186: 329-333

9 Krischel M. Urologie und Nationalsozialismus. Eine Studie zu Medizin und Politik als Ressourcen füreinander (Schriften zur Urologiegeschichte 1). Stuttgart: Steiner; 2014

10 Krischel $M$ et al. (eds). Urologen im Nationalsozialismus. Zwischen Anpassung und Vertreibung. 2 Bde. Berlin: Hentrich und Hentrich; 2011

11 Weyers W. Death of Medicine in Nazi Germany. Dermatology and Dermapathology under the Swastika. Philadelphia: Lippincott-Raven Publishers; 1998
12 Eppinger S. Das Schicksal der jüdischen Dermatologen Deutschlands in der Zeit des Nationalsozialismus (Mabuse Wissenschaft 51). Frankfurt am Main: Mabuse; 2001

13 Rauh P, Leven KH. Ernst Wilhelm Baader (1892-1962) und die Arbeitsmedizin im Nationalsozialismus (Medizingeschichte im Kontext 18). Frankfurt am Main: Peter Lang; 2013

14 Rohrbach JM. Augenheilkunde im Nationalsozialismus. Stuttgart/New York: Schattauer Verlag; 2007

15 Seidler E. Kinderärzte 1933-1945. Entrechtet - Geflohen - Ermordet. Bonn: Bouvier Verlag; 2000

16 Deutsche Gesellschaft für Kinderheilkunde. Die deutschen Kinderärzte gedenken ihrer verfolgten, aus dem Land getriebenen und ermordeten Kolleginnen und Kollegen 1933-1945 (Monatsschrift Kinderheilkunde 147/5, Suppl. 1). Berlin/Heidelberg: 1999

17 Jütte R. Die Vertreibung jüdischer und „staatsfeindlicher“ Ärztinnen und Ärzte. In: Jütte R (ed). Medizin und Nationalsozialismus. Bilanz und Perspektiven der Forschung. Göttingen: Wallstein Verlag; 2011: $83-93$

18 Schmidt M, Winzen T, Krischel M et al. Medizinische Fachgesellschaften im Nationalsozialismus - Bestandsaufnahme und Perspektiven. Tagung des Instituts für Geschichte, Theorie und Ethik der Medizin Aachen. 8./9. Oktober 2013 (Tagungsbericht). http://hsozkult.geschichte. hu-berlin.de/

19 Klee E. Deutsche Medizin im Dritten Reich. Karrieren vor und nach 1945. Frankfurt am Main: S. Fischer Verlag; 2001

20 Moser G. „Bestallungen (Approbationen) jüdischer Ärzte erlöschen am 30. September 1938“. Vor 75 Jahren entzog der NS-Gesetzgeber Ärztinnen und Ärzten die staatliche Berufszulassung. Fortschr Röntgenstr 2013; 185: 930 - 935

21 Fangerau $H$. Urologie im Nationalsozialismus - Eine medizinische Fachgesellschaft zwischen Professionalisierung und Vertreibung. In: Krischel M et al. (eds). Urologen im Nationalsozialismus. Zwischen Anpassung und Vertreibung. 1. Berlin: Hentrich und Hentrich; 2011: 13 21

22 Krischel M. Forschungsperspektiven zur Geschichte der Urologie in Deutschland, 1933-1945. Der Urologe 2010; 49: 1188-1193

23 Schmidt M, Groß D. Hans Holfelder und der Röntgensturmbann der Waffen-SS. Der Radiologe 2013; 53: 620f

24 Weiske K. Hans Holfelder - Radiologe in Frankfurt. Nationalsozialist, Gründer des SS-Röntgensturmbanns. In: Benzenhöfer U (ed). Mengele, Hirt, Holfelder, Berner, von Verschuer, Kranz: Frankfurter Universitätsmediziner der NS-Zeit. Münster: Klemm \& Oelschläger; 2010: 43 - 60

25 Benzenhöfer $U$. Friedrich Berner - Radiologe in Frankfurt, leitender Arzt des NS-,„Euthanasie-Zentrums in Hadamar. In: Benzenhöfer U (ed). Mengele, Hirt, Holfelder, Berner, von Verschuer, Kranz: Frankfurter Universitätsmediziner der NS-Zeit. Münster: Klemm \& Oelschläger; 2010: 61 - 78

26 Thom A. Der Reichsausschuß für Krebsbekämpfung und seine Wirksamkeit in den Jahren 1930 bis 1945. In: (ed). Eckart WU. 100 Years of Organized Cancer Research - 100 Jahre organisierte Krebsforschung. Stuttgart/New York: Thieme; 2000: 37-42

27 Behrendt $L D$, Schäfer $D$. Ein medizinischer „Mitläufer“? Rudolf Grashey und die Röntgenologie im „Dritten Reich“. In: Groß D et al. (eds). Medizingeschichte in Schlaglichtern. Beiträge des Rheinischen Kreises der Medizinhistoriker (Schriften des Rheinischen Kreises der Medizinhistoriker 2). Kassel: Kassel University Press; 2011: 227-242

28 Pieper C. Die Sozialstruktur der Chefärzte des Allgemeinen Krankenhauses Hamburg-Barmbek 1913 bis 1945. Ein Beitrag zur kollektivbiographischen Forschung (Veröffentlichungen des Hamburger Arbeitskreises für Regionalgeschichte 16). Münster/Hamburg/London: Lit; 2003

29 Montz R. Radiologische Klinik und Strahleninstitut. Vom „Röntgencabinett“ zum modernen Großinstitut. In: Weisser U (ed). 100 Jahre Universitätskrankenhaus Eppendorf 1889-1989. Tübingen: Attempto; 1989: $306-311$

30 Holfelder $H$. Die Organisation des Röntgendienstes an Universität und Krankenhaus. In: Grashey R (ed). Bericht über die 30. Tagung der Deutschen Röntgengesellschaft vom 24.-27. Mai 1939 in Stuttgart (Verhandlungen der Deutschen Röntgen-Gesellschaft 33) Fortschr Röntgenstr 1939; 60: 21-30

31 Westermann S. Verschwiegenes Leid. Der Umgang mit den NS-Zwangssterilisationen in der Bundesrepublik Deutschland (Menschen und Kulturen. Saeculum-Beihefte 7). Köln/Weimar/Wien: Böhlau; 2010 
32 Kühl S. Die Internationale der Rassisten. Aufstieg und Niedergang der internationalen Bewegung für Eugenik und Rassenhygiene im 20. Jahrhundert. Frankfurt am Main/New York: Campus; 1997

33 Rothmaler C. Sterilisationen nach dem „Gesetz zur Verhütung erbkranken Nachwuchses“ vom 14. Juli 1933. Eine Untersuchung zur Tätigkeit des Erbgesundheitsgerichtes und zur Durchführung des Gesetzes in Hamburg in der Zeit zwischen 1934 und 1944 (Abhandlungen zur Geschichte der Medizin und der Naturwissenschaften 60). Husum: Matthiesen; 1991

34 Roth KH. Tödliche Höhen: Die Unterdruckkammer-Experimente im Konzentrationslager Dachau und ihre Bedeutung für die luftfahrtme- dizinische Forschung des „Dritten Reichs“. In: Ebbinghaus A, Dörner K (eds). Vernichten und Heilen. Der Nürnberger Ärzteprozess und seine Folgen. Berlin: Aufbau-Verlag; 2001: 110-151

35 Ebbinghaus A, Roth KH. Ausgewählte Kurzbiographien zum Ärzteprozess. In: Ebbinghaus A, Dörner K (eds). Vernichten und Heilen. Der Nürnberger Ärzteprozess und seine Folgen. Berlin: Aufbau-Verlag; 2001: 617-645

36 Klee E. Auschwitz, die NS-Medizin und ihre Opfer. Frankfurt am Main: S. Fischer; 1997 